\title{
Morphology and Structure of Fruits of Some Desert Efemers of the Genus Alyssum L.
}

\author{
Gulbakhor Sultanovna Tursinbaeva \\ Pedagogical State University, Tashkent, Uzbekistan \\ Email: guljon.duschanova@mail.ru
}

How to cite this paper: Tursinbaeva, G.S. (2017) Morphology and Structure of Fruits of Some Desert Efemers of the Genus Alyssum L. American Journal of Plant Sciences, 8, 3443-3449. https://doi.org/10.4236/ajps.2017.813231

Received: October 16, 2017

Accepted: December 19, 2017

Published: December 22, 2017

Copyright $\odot 2017$ by author and Scientific Research Publishing Inc. This work is licensed under the Creative Commons Attribution International License (CC BY 4.0).

http://creativecommons.org/licenses/by/4.0/

\begin{abstract}
The structure of the fetus, seed, embryo of 3 species of ephemerals of the genus Alyssum, collected in the southwestern Kyzylkum, is described. Fetus of the Alyssum species is rounded, wide-pated silicle, with fetus stems of a truncated-conical ( $A$. dasycarpum) shape. Pericarp is $4-5$ layered. The fetus is seedless $(2-4)$, and the seeds are protein-free, with a large embryo. At the general plan of a structure, species have diagnostic signs distinguishing them on the form of a fetus, weight of seeds, the structure of embryo mesophyll.
\end{abstract}

\section{Keywords}

Anatomy, Fetus, Seeds, Embryo, Alyssum species, Kyzylkum

\section{Introduction}

Due to wide distribution of Alyssum species, the morphology of fetuses studied for a long time and from different perspectives. A. A. Alyavdina [1] studied the fetus for more than 100 species of Brassicaceae (including Alyssum) in terms of taxonomy and phylogeny of the taxon. The author noted the same structure of spermoderm, consisting of 5 (rarely $6-7$ ) layers, with a significant variety of their capacity and scleritis. The adaptive role of myxospermia and its complete absence in non-opening fetus are emphasized.

In the ecological aspect, the structure of the fetus of Alyssum species is discussed by S. Yu. Rozhanovsky [2], U. N. Zhapakova [3] [4], A. A. Butnik, G. S. Tursinbaeva [5], A. B. Georgievsky [6] and V. G. Minaev [7], A. I. Rudko [8] noted one of the factors of fetus adaptation to arid conditions is the presence of a pigment in the covers, which provides protection against ultraviolet radiation and accumulates heat. In the seed, oil contains ferulic acid and number of oleic acid [9]. A. C. Martin [10] referred the seeds of Brassicaceae to the axial (axile) 
direction, with a curved embryo and not a starchy endosperm.

\section{Material and Methods}

The material is collected from the southwestern Kyzylkum Desert Station. The region is characterized by extreme dryness of air and soil, caused by a minimum amount of precipitation ( $80-120 \mathrm{~mm}$ per year), high summer and low winter temperatures from max. $+40^{\circ} \mathrm{C}-45^{\circ} \mathrm{C}$ to $\min -25-30^{\circ} \mathrm{C}$ accompanied by a strong wind [11] [12] [13] [14] [15].

The morphology of fetus and seeds was studied according to the generally method developed by N.N. Caden [16], E.S. Smirnova [17], with some modifications described the sculpture of the fetus and the seed, and quantitative indicators: weight, size. Microscopic examination of the fetus was carried out on a material previously held for a month in a solution of Strasbourg-Flemming: alcohol, glycerin, water (1:1:1)

\section{Results and Discussion}

Alyssum dasycarpum. Fetus is a silicle in a loose penicil. Fetus in collective fruit is arranged by the rib to the axis. The peduncle is $1.7 \mathrm{~mm}$, pointing upwards. The silicle is oval, yellow-cream colored, convex on both sides. The fetus is tomentous with 6 - 10-rays star-shaped hairs. In the central part on the dorsal and ventral sides tomentous is very rare or completely absent (visible venation). At the top of the silicle there is a long fetus column $1.0-1.7 \mathrm{~mm}$ in length. The silicle bicorn with a thin transparent septum, webbed opening. Fruit length-3.3 $\mathrm{mm}$, width-3.0 mm. Each fruit contains 2 - 4 seeds (Table 1).

Seeds are oval-cylindrical, convex, light-brown with black specks, surrounded by a gray, opaque narrow border, which widens at the tip of the seed and forms two denticles. The seeds length: $1.2 \mathrm{~mm}$, width: $0.9 \mathrm{~mm}$. Weight: 1000 pcs.$0.35 \mathrm{~g}$. A seed cicatrix is between the teeth of the rim, from which a thin white funicle. The embryo is bent have a marginal root.

The spermoderm consists of 5 rows of cells. The outer layer-the epidermis (exotest) is single-rowed, in terms of polygonal cells is colorless thin-walled, with convex outer walls. This is the mucous layer. When the seeds are moistened with water, from the lower wall of the cell the colorless stems rise with a slight widening in the upper part, i.e. the mucus occurs. Under the epidermis there is one row of parenchymal cells with thickened walls. In the alar outgrowth of seeds, these cells are larger than other parenchymal cells.

The next 2 rows consist of elongated cells of a thin-walled compressed colorless parenchyma, and then follow a single-row pigment layer from tangentially elongated cells of green color. Under the spermoderm there are two rows of cells-the endosperm residue: the outer row of cells is proteinaceous, the inner-starch-like.

The mesophyll of the cotyledon of the embryo is $174 \pm 5.7 \mu \mathrm{m}$ thick, dorsiventral. Under the adaxial one-row epidermis there are 3 rows of palisade cells 
$26.2 \pm 1.6 \mu \mathrm{m}$ in height, $9.9 \pm 0.8 \mu \mathrm{m}$ in width, with a palisade factor of $52.6 \%$, and a palisade index of cells of 2.6.

The lower part of the hypocotyl in the transverse section is rounded, compressed in the area of adherence to the cotyledons, with a very large celled epidermis. The cells of the epidermis are covered with a thick cuticle and are elongated in a radial direction. The cells of the cow parenchyma are 5 - 7-faceted, large, small central cylinder surrounded by a large-cell endoderm.

Alyssum turkestanicum. Fetus is silicle in a thick penicil. The form of collective fruit is conical. Pedicel length $-1.9 \mathrm{~mm}$ obliquely pointing upward. The silicleis rounded, convex on both sides, with flat edges, cream colored, surrounded by a very narrow, thin, tomentous grayish fringe with well-marked venation.

Fruit column is truncated-conical. The silicle two-cavity opening membrane, has a thin transparent septum, $3.6 \mathrm{~mm}$ in length, $3.7 \mathrm{~mm}$ in width, and each fruit contains 2 - 4 seeds (Table 1 ).

The seed is obovate, convex only from the dorsal side, surrounded by a grayish border, which forms two denticles in the upper part of the seed. The

Table 1. Signs of the fruits of species of the genus Alyssum.

\begin{tabular}{|c|c|c|c|}
\hline Sign & A. dasycarpum & A. turkestanicum & A. szovitsianum \\
\hline \multicolumn{4}{|l|}{ Length, $\mathrm{mm}$ : } \\
\hline Peduncle & $1.7 \pm 0.2$ & $3.6 \pm 0.3$ & $1.9 \pm 0.3$ \\
\hline Fruit & $3.3 \pm 0.1$ & $4.0 \pm 0.2$ & $3.6 \pm 0.2$ \\
\hline Column & $1.0-1.7$ & $0.3-0.4$ & $0.4-0.7$ \\
\hline Fruit width, mm & $3.0 \pm 0.1$ & $3.6 \pm 0.2$ & $3.7 \pm 0.2$ \\
\hline \multicolumn{4}{|l|}{ Seed: } \\
\hline Length, mm & $2 \pm 0.1$ & $1.9 \pm 0.05$ & $1,60,3$ \\
\hline Width, mm & $0.9 \pm 0.05$ & 1.5 & $1,30,05$ \\
\hline Number of seeds in the fetus & $2-4$ & $2-4$ & $2-3$ \\
\hline Number of seeds in the nest & $2-4$ & $2-3$ & $4-5$ \\
\hline Weight 1000 pcs., g & $0.35 \pm 0.02$ & $0.85 \pm 0.05$ & $0.37 \pm 0.03$ \\
\hline \multicolumn{4}{|l|}{ Signs embryo cotyledons } \\
\hline \multicolumn{4}{|l|}{ Thickness, $\mu \mathrm{m}$ : } \\
\hline Mesophyll & $174 \pm 5.7$ & $204.8 \pm 3.2$ & $221.1 \pm 4.8$ \\
\hline The palisade layer & $92.1 \pm 3.6$ & $99.7 \pm 2.6$ & $98.4 \pm 3.8$ \\
\hline \multicolumn{4}{|l|}{ Coefficient } \\
\hline Palisade, \% & 52.6 & 48.7 & 44.5 \\
\hline \multicolumn{4}{|l|}{ Palisade cells, $\mu \mathrm{m}:$} \\
\hline Height & $26.2 \pm 1.6$ & $18.5 \pm 1.0$ & $23.6 \pm 0.9$ \\
\hline Width & $9.9 \pm 0.8$ & $9.9 \pm 0.8$ & $9.4 \pm 0.4$ \\
\hline Index of palisade & 2.6 & 1.86 & 2.5 \\
\hline
\end{tabular}


surface of the seed together with the rim is small-pointed, slightly shiny. The seed is $1.6 \mathrm{~mm}$ long, $1.3 \mathrm{~mm}$ wide, brown in color. Weight: 1000 pcs. $-0.37 \mathrm{~g}$. Under one of the denticles departs a white thin funiculus. The embryo is marginal root.

The mesophyll of the cotyledons is dense, $221.1 \pm 4.8 \mu \mathrm{m}$ thick, dorsiventral. The palisade parenchyma is 3 rows, occupies $98.4 \pm 3.8 \mu \mathrm{m}$ of transverse section (44.5\%), spongy parenchyma -5 - 6 rows. The height of the palisade cells is 23.6 $\pm 0.9 \mu \mathrm{m}$; the width is $9.4 \pm 0.4 \mu \mathrm{m}$; the palisade index is 2.5 . In the tissues of cotyledons there are many fatty substances.

Alyssums zovitsianum. Fetus-silicle in the collective fruit-a thick oblong-ovate spike. In the collective fruit, the fetus are tegular, the pedicels $3-4$ $\mathrm{mm}$ long, tightly pressed against the axis (Figure 1).

The silicle lentiform, dorsal is convex, ventral edge slightly concave, sand-gray. The fruit is surrounded by a thin, strong grayish fringe. Venation is seen in the central part of the dorsal surface of the fruits. The surface of the silicle is covered with 8 - 12 ray hairs, more dense on the ventral side. The fruit column is short, $0.3-0.4 \mathrm{~mm}$, truncated-conical with a bifurcated upper part. The silicle is two-caved with 2 - 4 seeds, opening membranous, with a thin transparent septum (Table 1 ).

The seeds are brown with a punctulate, slightly glossy surface, broadly obovate, flat on the ventral side, convex in the dorsal side, surrounded by a jelly-whitish fringe, which forms two denticles in the narrow part of the seed. Seeds are $1.9 \mathrm{~mm}$ in length and $1.5 \mathrm{~mm}$ in width. Weight: 1000 pcs. $-0.85 \mathrm{~g}$. A seed cicatrix is located between the denticles of the rim, from which the white thin seed-leg leaves. The embryo is bent, marginal root (Figure 1).

Spermoderm consists of 3 layers of cells. The outer layer-the epidermis (exotest) consists of one row of colorless thin-walled, polygonal cells representing the mucous layer and having convex outer walls. Colorless stems rising from the lower walls of the cells, when swollen, expand like mushroom. Under the epidermis is a row of parenchymal cells with thickened walls. In the alar outgrowth area, these cells are approximately 5 times larger than the cells of the thick-walled parenchyma. The next 2 rows consist of colorless cells of thin-walled parenchyma, strongly elongated tangentally. Then follows a single-row pigment layer, as well as the previous, formed by tangentially elongated cells of dark green color (endotest). Under the spermoderm are 2 rows of cells the endosperm residue: the outer layer is proteinaceous, the inner layer is starch-like (Figure 1).

The mesophyll of the cotyledon of the embryo is $204.8 \pm 3.2 \mu \mathrm{m}$ thick, dorsiventral. Under the upper one-row epidermis there are 4 rows of palisade cells with a thickness of $99.7 \pm 2.6$ microns ( $48.7 \%$ of the transverse section). The palisade cells with a height of $18.5 \pm 1.0 \mu \mathrm{m}$, a width of $9.9 \pm 0.8 \mu \mathrm{m}$, with a palisade index of 1.9. Spongy cells form 6 rows (Figure $1(\mathrm{~d})$ ).

The lower part of the hypocotyl of the embryo is rounded, compressed in the 


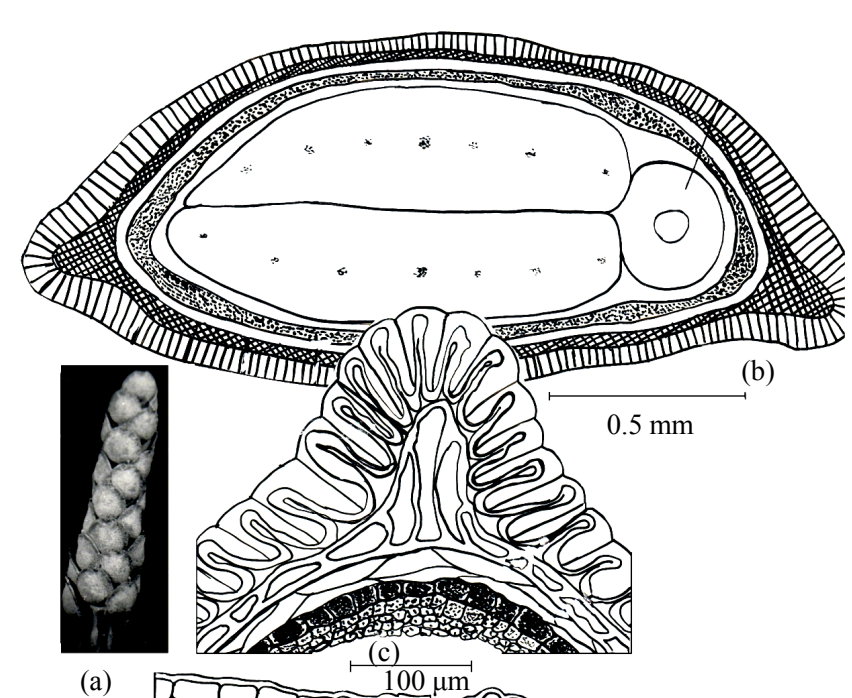

(a)



(d)

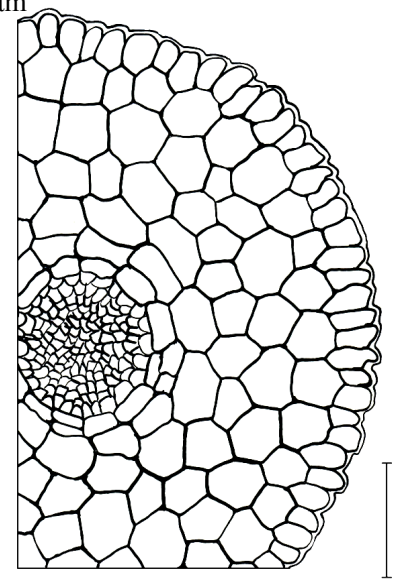

(e)
$50 \mu \mathrm{m}$

Figure 1. The structure of the fetus Alyssum szovitsianum: (a) the appearance of the fruit; (b) scheme of the transverse section of the fetus; (c) spermoderm; (d) cotyledon; (e) axial part of the embryo.

area of adherence to the cotyledons, with very large epidermal cells elongated to radial direction. Cells of the cortex of the parenchyma are isodiometric, 5 - 7 faceted, large, rounded. The central cylinder is surrounded by a large-cell endoderm (Figure 1).

The structure of spermoderm $A$. turkestanicum was previously described by S.Yu. Rozhanovsky [2]. We clarified some details to his description. The spermoderm is thin, consists of 5 layers: an exoderm consisting of mucous cells (complete myxospermia); the underlying layer consisting of thick-walled large cells; the pigment layer, performing a mechanical function, due to its impregnation with flavonoids or flabophenes. The aleuron layer and the inner 2 - 3 rows, adjacent to the embryo, represent the residue of the endosperm.

A comparative analysis of the fetus of Alyssum revealed the following differences in species. The fetus of Alyssum species is a silicle in a loose (A. dasycarpum) or dense conical brush (A. turkestanicum), in a dense oblong-ovate band (A. szovitsianum). The peduncles are directed upwards (A. dasycarpum), obli- 
quely upward (A. turkestanicum) or pressed tightly to the axis (A. szovitsianum). The silicle is oval, convex on 2 sides (A. dasycarpum), rounded with flat margins and narrow gray border ( $A$. turkestanicum) or lentiform convex from dorsal side and concave with peritoneum (A. szovitsianum). Fetus, tomentous with 6 - 10 radial stellate trichomes along the edges, sparse on the dorsal ventral side (A. dasycarpum), nontomentous (A. turkestanicum) or tomentous with 8 12 radial trichomes more from the ventral side ( $A$. szovitsianum). The column is truncated from 0.3 to $1.7 \mathrm{~mm}$ (tab.), the longest in A. dasycarpum.

The silicle of all species bilobates with a thin transparent partition opened, larger in A. turkestanicum 2 - 4 seeds. The seeds oval-cylindrical, convex ( $A$. dasycarpum), obovate, convex on the side of the back (A. turkestanicum) or broadly obovate, flat on the ventral side, convex from the back. The seeds are surrounded by a border of various shapes: opaque narrow, on the apex of the generatrix of 2 denticles ( $A$. dasycarpum), gelatinous-whitish in a narrow part with 2 denticles (A. szovitsianum) and grayish with 2 denticles and (A.turkestanicum).

The surface of the seeds is light brown with black specks (A. dasycarpum), punctulate slightly glossy ( $A$. turkestanicum), a brown punctulate shiny. The size of the seeds is almost the same, slightly smaller in A. turkestanicum and it has a mass of 1000 pcs. seeds the largest. The embryo of all species is marginal. Pericarp is sclerosed, however, the main function of protection is performed by spermoderm.

\section{Conclusion}

Thus, according to A.C. Martin [10], seeds of the family Brassicaceae are referred to the axial (axile) direction, the bent type of embryo located centrally, and the endosperm is non-starchy. They are characterized by a germ with an axial part of the same or almost the same length with cotyledons. In the studied species, the root protrudes above the cotyledons. This feature probably has an advantage in germination of seeds. Cotyledons of the studied species of dorsiventral type differ in the number of rows of palisade parenchyma, thickness of the mesophyll and other indices. The structure of the fruit covers and spermoderm of desert species of Alyssum provides reliable protection and is adapted to germination of the embryo during the short wet period.

\section{References}

[1] Alyavdina, A.A. (1931) The Importance of the Anatomy of Fruits and Seeds for the Systematics of the Family Cruciferae. Journal of Russian Bot. Society, 1, 85-100.

[2] Rozhanovsky, S.Yu. (1961) Anatomical Features of Seeds and Some Ephemerals and Ephemeroids of the Deserts of Middle Asia. Academy of Sciences of the Uzbek SSR, 20.

[3] Japakova, U.N. (1991) Adaptive Features of the Structure of Fruits and Seeds of Wild-Growing Plants in the South-Western Kyzylkum. Journal of Cytology, 33, 101-109. 
[4] Japakova, U.N. (2001) The Ecological Importance of Structural Parameters of Fruits and Seeds of the Ephemerals of Kyzylkum. Problems and Prospects of Biological, Ecological Education. Tashkent, 29-30.

[5] Butnik, A.A. and Tursinbaev, G.S. (2017) Ephemerals of the Kyzylkum: Morphology, Structure, Adaptive Strategy. Fan, Tashkent, 256.

[6] Georgievsky, A.B. (1981) On the Elementary Evolutionary Phenomenon. Problems of the Recent History of Evolutionary Teaching. Science, Leningrad, 46-55.

[7] Minaeva, V.G. (1978) Flavonoids in Plant Ontogeny and Their Practical Use. Science, Novosibirsk, 254.

[8] Rudko, A.I. (1997) Anatomic Features of the Pericarp of Some Representatives of the Family. Cruciferae due to the Nature of Dissemination. In: International Conference on the Anatomy and Morphology of Plants, Dyad, St. Petersburg, 113-114.

[9] Avetisyan, V.E. (1988) Chemical Properties of Macrotaxonomy of the Family. Brassicaceae. Topical Issues of Botany in the USSR. Theses of the Scientific Conference, Science, Alma-Ata, 8-9.

[10] Martin, A.C. (1946) The Comparative Internal Morphology of Seeds. The American Midland Naturalist, 36, 513-660. https://doi.org/10.2307/2421457

[11] Momotov, I.F. (1962) Kyzylkum Desert Station. The Botanical Journal, 47, 1858-1862.

[12] Babushkin, L.N. (1971) Physical and Geographical Conditions of Uzbekistan. Climate. Vegetative Cover of Uzbekistan. FAN, Tashkent, 48-62.

[13] Gorbunov, B.V. and Kimberg, N.V. (1971) Physical and Geographical Conditions of Uzbekistan. Vegetative Cover of Uzbekistan. FAN, Tashkent, 63-74.

[14] Lee, A.D. (1973) Rhythm of Development and Bioecological Productivity of the Main Communities of Southwestern Kyzylkum. Theoretical Foundations and Methods of Phytomelioration of Desert Pastures of Southwestern Kyzylkum. FAN, Tashkent, 36-59.

[15] An, P.A., Gringof, I.G. and Konovalov, N.S. (1978) Microclimatic Features of Some Landscapes of Southwestern Kyzylkum. Hydro Meteorological Center, Moscow, 64-94.

[16] Caden, N.N. (1961) On Some Basic Questions of Classification, Typology and Nomenclature of Fruits. Botanical Journal, 46, 496.

[17] Smirnova, E.S. (1965) Types of Structures of Seeds of Flowering Plants with a Phylogenetic Aspect. Journal of General Biology, 26, No. 3. 